\title{
TRANSPORTATION SYSTEM ROUTE OPTIMIZATION OF MUNICIPAL SOLID WASTE - CASE OF SOUTH OF THE BLACK SEA
}

\author{
Oylum Gokkurt Baki ${ }^{{ }^{*}}$, Muhammet Yakan ${ }^{2}$ \\ ${ }^{*}$ Sinop University, Engineering and Architecture Faculty, Environmental Engineering Department, 57000, Turkey; \\ ${ }^{2}$ Sinop University, Interdisciplinary Enironmental Health Programme, Institue of Science, 57000, Turkey; \\ Corresponding Author Oylum Gokkurt Baki, e-mail:*oylumbaki@gmail.com; muhammetyakan.my@gmail.com;
}

Received March 2019; Accepted April 2019; Published May 2019;

DOI: https://doi.org/10.31407/ijees9212

UOI license: http://u-o-i.org/1.01/ijees/94478583

\begin{abstract}
In parallel with rapid population growth, technological developments and rising living standards, the amount of solid waste is increasing day by day. Municipalities spend a large amount of money to collect, transport and dispose of solid wastes in Turkey. In municipal solid waste management systems, $85 \%$ or even more of the total system cost constitutes collection/hauling operations. However, only the collection of solid wastes and transport from different points of the city to disposal sites in an environmentally and economically sustainable way is not enough to solve the problem. At this point, cost reduction can be done by recounting the routes on the collection/hauling operations and conducting evaluation studies on the existing system. The most sustainable solution to this issue it is surely beyond doubt that waste minimization and recycling. However, waste collection is still ongoing in many cities in the country. This study is an exemplary study for municipalities that are currently working on waste collection in Turkey. The aim of this study is to investigate the improvement of collection and transportation system of urban solid wastes in Sinop city center in Turkey. A study was carried out in Sinop City Center to determine routes and container points to represent the summer and winter seasons, together with the vehicle carrying the collection/transportation. At this stage, the field study was started and the coordinates of the containers were recorded with Garmin brand handheld GPS device between May-2017 and September-2017. Since the summer and winter population of Sinop city center is very variable, the evaluation is carried out in two stages as summer and winter. In practice, 365 containers for Sinop Province were found in total. All specified coordinate data has been exported to Google Earth Pro and routes have been defined for 3 different regions. After these variables are determined, the number of container distances obtained is evaluated manually based on various variables such as the duration of the vehicle's stopping period. In addition to these applications, it has been moved to the coordinate transformation vector by using MapInfo Pro software by moving the coordinates by using the pick-and-move tool. Here, too, the aim was to collect the shortest existing containers as soon as possible. Mapinfo Pro site ArcGis 10.2 software is used for this. In addition, some of the improvements and suggestions for the solid waste collection and transportation in Sinop province are also presented. Although it is possible to achieve economic gains with some route improvements, among the results obtained without working, there is the necessity of considering and implementing the subject in order to achieve continuous participation and education of the people. In addition, the need for more efficient systems such as dual collection and waste collection centers is also among the results. After performing routes by the software, the optimized routes were compared with the present routes. Success by the optimization process was around $30-57 \%$ in general for distance and $10 \%$ for time in general. Consequently, a route optimization process on the street stationary container collection system will contribute a benefit by $49 \%$ in total cost.
\end{abstract}

Key words: Municipal solid waste, solid waste management, Collecting/hauling system, sustainable solid weste management, Black Sea, Turkey 